
053620190211

\title{
Associations between morphological and agronomic characteristics in garlic crop
}

\author{
Valter C de Andrade Júnior ${ }^{1} \mathbb{D}$; Amanda G Guimarães ${ }^{2} \mathbb{D}$; Tiago D Firme ${ }^{1} \mathbb{D}$; Aline Aparecida A Costa ${ }^{2} \mathbb{D}$; \\ Márcia Regina da Costa ${ }^{2} \mathbb{D}$; Thabata Karoline Lopes ${ }^{1} \mathbb{D}$; Rovilson José de Souza ${ }^{1} \mathbb{D} ;$ Francisco V Resende ${ }^{3} \mathbb{D}$
}

${ }^{1}$ Universidade Federal de Lavras (UFLA), Lavras-MG, Brazil; valter.andrade@ufla.br; tiagodiniz62@hotmail.com; thabata_lopes15@ yahoo.com.br; rovilson@ufla.br ${ }^{2}$ Universidade Federal dos Vales do Jequitinhonha e Mucuri (UFVJM), Diamantina-MG, Brazil;

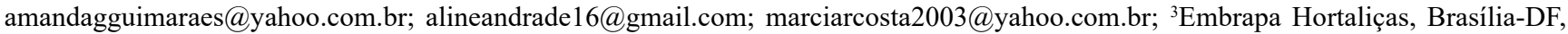
Brazil; francisco.resende@embrapa.br

\begin{abstract}
Correlations and path analysis between characteristics can aid the selection of important attributes in breeding programs. Thus, the objective of this work was to perform genotypic, phenotypic correlations and path analysis under commercial yield of garlic bulbs, depending on morphological and agronomic variables. The experiment was carried out in 2017 at the Universidade Federal dos Vales do Jequitinhonha e Mucuri and Universidade Federal de Lavras, using ten garlic genotypes, eight trials and two commercial cultivars, Caçador and Jonas. We evaluated: plant height; number of leaves, total bulb number; total bulb mass, total bulb yield, marketable bulb yield and number of cloves per bulb. The genotypic and phenotypic correlations were positive and significant between marketable yield of bulbs with bulb mass, total yield and number of cloves per bulb, indicating that selection based on these characteristics will help increase the yield of garlic. However, only the number of cloves per bulb had a direct effect and a relevant indirect effect on the marketable yield of garlic.
\end{abstract}

Keywords: Allium sativum, genetic improvement, indirect selection.

\section{RESUMO}

Associações entre características morfológicas e agronômicas na cultura do alho

Correlações e análise de trilha entre características podem auxiliar na seleção de importantes atributos em programas de melhoramento genético. Assim, o objetivo deste trabalho foi avaliar correlações genotípicas, fenotípicas e realizar análise de trilha sob a produtividade comercial de bulbos de alho em função de variáveis morfológicas e agronômicas. O experimento foi realizado em 2017 na Universidade Federal dos Vales do Jequitinhonha e Mucuri e Universidade Federal de Lavras utilizando dez genótipos de alho, sendo oito experimentais e duas cultivares comerciais, Caçador e Jonas. Foram avaliadas: altura de plantas; número de folhas, número de bulbo total; massa de bulbo total, produtividade total de bulbo, produtividade comercial de bulbo e número de bulbilhos por bulbo total. As correlações genotípicas e fenotípicas foram positivas e significativas entre a produtividade comercial de bulbos com massa de bulbo, produtividade total e número de bulbilhos por bulbo total, indicando que a seleção baseada nessas características ajudará a aumentar o rendimento do alho. Entretanto, apenas o número de bulbilhos por bulbo apresentou efeito direto e efeito indireto relevante sobre a produtividade comercial de alho.

Palavras-chave: Allium sativum, melhoramento genético, seleção indireta.

Received on September 20, 2018; accepted on April 26, 2019

$\mathrm{I}^{\mathrm{n}}$ genetic improvement programs, there is a constant search to bring together in a single individual several characters of interest, to meet both demands, of the producer and the consumer. In this scenario, garlic cultivation (Allium sativum), in addition to obtaining greater total bulb yields, is also sought for quality for the market with a high marketable yield that considers the diameter of the bulb larger than $37 \mathrm{~mm}$ (Brazil, 1992).
Garlic has been described as a sterile species or as a typical apomictic obligatory plant (Etoh, 1980), being propagated asexually, by means of cloves taken from the base of the plant, or by aerial cloves of the inflorescences (Pooler \& Simon, 1993). Therefore, the classic improvement of this vegetable, through crossings to increase the genetic variability, has been discarded, being possible the selection on already existing materials, of germplasm banks, identifying the superior ones for specific conditions of each culture environment (Souza \& Macêdo, 2009).

In addition, selecting superior garlic genotypes is not an easy task, since bulb yield has a complex genetic action and, in order to study it properly, one must evaluate the environment and other characteristics that may contribute to production (Chotaliya \& Kulkarni, 2017). The use of statistical tools can aid in such evaluations, such as correlation 
and path analysis (Cruz et al., 2012).

Correlations are measures of associations between two characteristics that quantify the magnitude and direction of the influences of one characteristic on another, and may help in the indirect selection of one without the need to evaluate the other one leading to faster progress (Cruz et al., 2012; Singh et al., 2013; Rezende \& Silva, 2015). High magnitude indicates the existence of a linear relationship between the studied characteristics. About the direction, when signs are equal, positive or negative, it is interpreted that the two characters are benefited or harmed by the same causes of variations; however, opposite signs of correlation determine that an increase in one characteristic greatly diminishes the other character (Singh et al., 2011; Chotaliya \& Kulkarni, 2017).

However, in certain cases, correlation coefficients can produce great misconceptions about the relationship between two variables, and may not be an actual measure of cause and effect, due to the indirect interference of another characteristic. To correct this obstacle, path analysis is used, which measures the direct and indirect effects between characteristics under a main variable, in addition to measuring the relative importance of the characteristic(s) that contribute most to the studied objective (Cruz et al., 2012).

Although there have been reports in the literature on correlation studies and path analysis in garlic culture (Dubey et al., 2010; Singh et al., 2010; Chotaliya \& Kulkarni, 2017), there is a need to investigate the combination of different characteristics under commercial production of garlic genotypes that were not developed in the cultivation regions, in Diamantina and Lavras, both in the State of Minas Gerais, Brazil. Thus, the objective of this work was to estimate genotypic, phenotypic correlations and path analysis under the commercial yield of garlic bulbs as a function of morphological and agronomic variables, in order to permit the selection of potential characteristic(s) which may lead to higher garlic production.

\section{MATERIAL AND METHODS}

\section{Genetic material}

Ten garlic genotypes were evaluated, two commercial noble garlic cultivars registered at the Ministry of Agriculture, Livestock and Supply (MAPA): Jonas (MAPA Registry $n^{\circ} 14178$ ) and Caçador (MAPA Registry $n^{\circ}$ 01967) and eight experimental garlic genotypes (DDR 6811, DDR 6822, W6 12832, U8 74, RAL 75, RAL 159, RAL 41, PI 540351) from the United States Department of Agriculture (USDA).

\section{Location and trial installation}

The trials were installed in two environments: in the Olericultura sectors of Universidade Federal dos Vales do Jequitinhonha e Mucuri, in Diamantina-MG $\left(43^{\circ} 36^{\prime} 01^{\prime \prime} \mathrm{W}\right.$, $18^{\circ} 14^{\prime} 58^{\prime \prime} \mathrm{S}, 1296 \mathrm{~m}$ altitude), 522.2 $\mathrm{mm}$ average precipitation and average temperature around $17.5^{\circ} \mathrm{C}$; and Universidade Federal de Lavras, LavrasMG ( $21^{\circ} 14^{\prime} \mathrm{S}, 45^{\circ} 00^{\prime} \mathrm{W}, 918 \mathrm{~m}$ altitude), $1486 \mathrm{~mm}$ average precipitation and $19.9^{\circ} \mathrm{C}$ average temperature. Soil was prepared by the conventional process and basic fertilization was carried out according to the recommendations of the $5^{\text {th }}$ approach for garlic cultivation (Souza et al., 1999), based on soil chemical analysis for each region.

Garlic genotypes were planted on June 2, 2017 in Diamantina and, May 27, 2017 in Lavras. Plots consisted of beds $0.2 \times 1.25 \times 20 \mathrm{~m}$ in height, width and length respectively, five planting lines. The cloves were planted at $5 \mathrm{~cm}$ depth, $20 \mathrm{~cm}$ spacing between rows and $10 \mathrm{~cm}$ between plants. Each plot of the treatments had 100 plants, being distributed in 4 beds, totaling 400 cloves per genotype. The three central rows were defined as useful area of the plot and the borders were constituted by two external rows and $10 \mathrm{~cm}$ of both ends of each plot, thus remaining with a floor area of $1.5 \mathrm{~m}^{2}$ (60 plants). The experimental design was randomized blocks, with ten genotypes and four replicates, which were represented by each plot in two growing environments.

Evaluation of morphological and agronomic characteristics

The harvest date was determined by yellowing and drying $2 / 3$ of the aerial part or bending of the plants. This stage was observed between October 01 and 15, 2017, for cultivars Caçador and Jonas and between November 01 and 22, 2017 for the other genotypes in Diamantina. In Lavras this stage was observed from October 16, 2017, for cultivars Caçador and Jonas and between October 31 and November 23, 2017 for the other genotypes. After harvest, plants were submitted to the curing process during 50 days in a greenhouse and afterwards, bulbs were cleaned.

Twelve plants of the three central lines per plot were evaluated, four plants of each row, 100 days after planting date: 1) average plant height (AP), measured from the soil level to the end of the longest leaf and expressed in $\mathrm{cm}$; 2) number of leaves (NF), determined by the average count of photosynthetically active leaves.

After the curing period, bulbs were classified (measurement of diameter using a digital caliper), according to

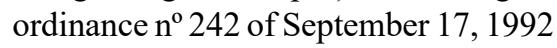
of the Ministry of Agriculture, Livestock and Supply (MAPA): class 3 ( $>32-37$ $\mathrm{mm})$, class $4(>37-42 \mathrm{~mm})$, class 5 $(>42-47 \mathrm{~mm})$, class $6(>47-56 \mathrm{~mm})$ and class $7(>56 \mathrm{~mm})$. For each plot: 1) total bulb number (NBT), counting all bulbs in the plot; 2) total mass of the bulbs (MBT), ratio between the mass under the total number of bulbs, expressed in g; 3) total bulb yield (PT) and marketable bulb yield (PC) (class 4 onwards), expressed in $\mathrm{tha}^{-1}$; 4 ) average number of cloves per bulb $(\mathrm{Nb})$.

\section{Statistical analysis}

The variance analysis was performed by environment and, later, the homogeneity of residual variances (QMRs) was verified through relationship between the highest and the lowest QMR (Gomes \& Garcia, 2002). When this relation was found to be less than seven, the analysis of joint variance was performed, considering the randomized block design, based on the following statistical model:

$Y_{i j k}=\mu+B / A_{j k}+G_{i}+A_{j}+G A_{i j}+e_{i j k}$ where: Yijk $=$ effect of the $i^{\text {th }}$ genotype in the $\mathrm{j}^{\text {th }}$ environment and in the $\mathrm{k}^{\text {th }}$ block; $\mu=$ general constant; B/Ajk = effect of the $\mathrm{k}^{\text {th }}$ block within the $\mathrm{j}^{\text {th }}$ environment; $\mathrm{Gi}=$ random effect of the $\mathrm{i}^{\text {th }}$ genotype $(\mathrm{i}=1,2, \ldots 10) \sim \mathrm{NID}\left(0, \sigma^{2} \mathrm{~F}\right) ; \mathrm{A}=$ fixed effect of the $\mathrm{j}^{\text {th }}$ environment $(\mathrm{j}=$ $1,2) ;$ GAij $=$ effect of the interaction 
of the $\mathrm{i}^{\text {th }}$ genotype with $\mathrm{j}^{\text {th }}$ environment; eeijk $=$ effect of the experimental error associated with the observation Yijk, considering eijk $\sim \operatorname{NID}\left(0, \sigma^{2}\right)$.

For the estimates of phenotypic (rF) and genotypic correlations ( $\mathrm{rG}$ ), data from the analysis of variance were used, according to the following expressions

and

$$
\mathrm{rF}=\frac{\operatorname{covF}(\mathrm{X}, \mathrm{Y})}{\sqrt{\sigma_{\mathrm{FX} .}^{2} \sigma_{\mathrm{FY}}^{2}}}
$$

$$
\mathrm{rG}=\frac{\operatorname{covG}(\mathrm{X}, \mathrm{Y})}{\sqrt{\sigma_{\mathrm{GX}}^{2} \sigma_{\mathrm{GY}}^{2}}}
$$

where: $\mathrm{COV}_{\mathrm{F}(\mathrm{X}, \mathrm{Y})}$ and $\mathrm{COV}_{\mathrm{G}(\mathrm{X}, \mathrm{Y})}$ correspond respectively to the estimates of phenotypic and genotypic covariance between the characteristics $\mathrm{x}$ and $\mathrm{y}$; $\sigma^{2} \mathrm{FX}$ and $\sigma^{2} \mathrm{GX}$ correspond to the estimates of phenotypic and genotypic variances of characteristic $\mathrm{x}$; and $\sigma^{2} \mathrm{FY}$ and $\sigma^{2} \mathrm{GY}$, correspond to the phenotypic and genotypic variances of characteristic $y$. The statistical test used for significance of the phenotypic correlation was made by the $\mathrm{T}$ test and the genotypic correlation by bootstrap resampling (number of simulations used) (Cruz et al., 2012).

Before performing path analysis, the degree of multicollinearity of the $\mathrm{X}^{\prime} \mathrm{X}$ matrix was estimated based on its number of conditions (NC), which is the ratio between the largest and the smallest eigenvalue of the $X^{\prime} X$ correlation matrix (Montgomery et al., 2012). This criterion considers that multicollinearity will be weak between the explanatory variables only when the ratio between the highest and the lowest eigenvalues is equal to or below 100 . When $\mathrm{NC}$ resulting from this division is $100<\mathrm{NC}<1,000$ it is considered that there is moderate to severe multicollinearity, and for $\mathrm{NC} \geq 1,000$, severe multicollinearity is considered.

For path analysis, the resolution in the matrix form was obtained according to the equation: $X^{\prime} X \beta=$ $X^{\prime} Y$, where $X^{\prime} X$ is a non-singular matrix of the correlations between primary variables; $\beta$ is the vector of column path coefficients, and $\mathrm{X}^{\prime} \mathrm{Y}$ is the column vector of correlations between the explanatory variables and dependent variable. The genotypic correlation was used in the analysis of the path between dependent variable (marketable bulb yield) and the explanatory variables (other characteristics), according to equation:

$$
r_{i x}=P_{i x}+\sum_{j \neq i}^{n} r_{j} P_{j x}
$$

where $r_{i x}$ is the correlation between the dependent variable and the $\mathrm{i}^{\text {th }}$ explanatory variable; $\mathrm{P}_{\mathrm{ix}}$ is the direct effect of the variable $i$ on the dependent variable; $r_{j} P_{j x}$ is the indirect effect of the variable $i$, via variable $\mathrm{j}$ under the dependent variable. All calculations related to the statistical analyzes were performed using Genes software (Cruz, 2013).

\section{RESULTS AND DISCUSSION}

After obtaining an analysis of the individual variance of each environment, the homogeneity of residual variances in all characters, with the ratio of highest to least average squares of residue (QMR greater / lower QMR) lower than seven was verified (Gomes \& Garcia 2002), the analysis of joint variance was performed.

Before the correlation and path analysis, we verified that for the main characteristics, total yield and commercial yield of bulbs, there was interaction between genotypes and cultivation environments, and it was necessary to investigate if this predominant interaction was of the simple or complex type.

The occurrence of most of the interaction between genotype and environment attributed to the simple part, above $50 \%$, indicates the same recommendation for both environments (Pereira \& Amaral Junior, 2001). Considering the methodology of Cruz \& Castoldi (1991), the predominant interaction was of the simple type, $68.8 \%$ and $66.9 \%$ for total and marketable yield of bulbs respectively, that is, the majority of genotypes did not have their classification or ranks among the environments, thus, the correlation analysis and path analysis performed with the joint analysis.

The correlations may be of phenotypic, genotypic and environmental nature. The first refers to measurement in observable characteristics including genotypic and environmental action. Genotypic correlation provides an inference about the genetic makeup of an individual being then inheritable in nature. And finally, environmental correlation plays the expression of the cultivated genotype at a given location (Cruz et al., 2012; Singh et al., 2013).

Some estimated genotypic and phenotypic correlations were significant (Table 1). Genotypic correlations were higher in relation to the phenotypic ones, thus evidencing higher contributions of genetic factors between characteristics in the two cultivation environments. High genetic correlations may be useful in the selection of superior genotypes in genetic breeding programs, since it allows indirect gains to be obtained by selecting a genotype based on a character that has another positively correlated (Dubey et al., 2010; Singh et al, 2013, Chotaliya \& Kulkarni, 2017). The characteristics of difficult measurements in the present study were plant height and number of leaves (to be carried out in the field in twelve plants per plot) and the commercial yield of bulb, having to classify each bulb on diameter, being commercial those presenting diameter greater than $37 \mathrm{~mm}$.

Plant height had a significant and positive correlation with the total bulb weight $(\mathrm{rG}=0.75$ and $\mathrm{rF}=$ 0.70 ), showing that the selection of garlic genotypes with higher heights gives higher masses of total bulb. This association could favor the productivities of total and marketable bulbs since the correlation of these two characteristics (PT and PC) with the total bulb mass was significant (PT: $\mathrm{rG}=0.99$ and $\mathrm{rF}$ $=0.91 ; \mathrm{PC}: \mathrm{rG}=0.99$ and $\mathrm{rF}=0.89$ ), thus causing time saving on evaluation and calculation of bulb yield. However, between plant height and number of leaves, the correlations were significant and negative $(\mathrm{rG}=-0.82$ and $\mathrm{rF}=-0.66)$, showing that the higher the plant height the fewer the number of leaves. This result possibly is that the majority of the plants occurred dewatering the leaves reducing the number of leaves per plant. Leaf efflorescence occurs due to the high activity of hormones (auxin), 
which causes them to grow excessively by expending their reserves, little light availability, either by competition between plants or low insolation at the time of cultivation (Moravcevic et al., 2011; Silva et al., 2016) and/or lack of adaptation of the garlic genotypes at the cultivation sites. Because it is a C3 plant, competition between plants becomes even more sensitive to its accumulation of biomass, since they require a higher concentration of atmospheric carbon to activate Rubisco (Shimono 2011; Yao et al., 2015).

It is known that leaves are of great importance to carry out photosynthesis and thus accumulate photoassimilates for the development of the organs (Singh et al., 2013). Photosynthesis depends on leaf area, because it is with an adequate leaf area that the interception of the solar rays will be more efficient, and consequently the yield of the crop will be higher (Pereira \& Machado, 1987; Yao et al., 2015). However, in the present study, the number of leaves was negatively correlated with total yield of bulbs $(\mathrm{rG}=-0.62$ and $\mathrm{rF}=$ $-0.51)$, that is, the higher the number of leaves the lower the total bulb yield. This may have occurred because leaves had a narrow width giving smaller leaf

Table 1. Estimates of phenotypic (rF) and genotypic ( $\mathrm{rG}$ ) correlations among seven morphological and agronomic characteristics evaluated in ten garlic genotypes. Diamantina and Lavras, UFVJM and UFLA, 2017.

\begin{tabular}{|c|c|c|c|c|c|c|}
\hline Characteristics & NF & NBT & MBT & PT & PC & $\mathbf{N b}$ \\
\hline \multirow{2}{*}{ AP } & $r_{\mathrm{F}}-0.66^{*}$ & $0.12^{\text {ns }}$ & $0.70 * *$ & $0.65^{\text {ns }}$ & $0.56^{\mathrm{ns}}$ & $0.37^{\text {ns }}$ \\
\hline & $\mathrm{r}_{\mathrm{G}} \quad-0.82^{+}$ & $0.14^{\mathrm{ns}}$ & $0.75^{+}$ & $0.71^{\mathrm{ns}}$ & $0.62^{\mathrm{ns}}$ & $0.37^{\mathrm{ns}}$ \\
\hline \multirow{2}{*}{ NF } & $\mathrm{r}_{\mathrm{F}}$ & $-0.18^{\mathrm{ns}}$ & $-0.48^{\mathrm{ns}}$ & $-0.51 *$ & $-0.47^{\mathrm{ns}}$ & $-0.34^{\text {ns }}$ \\
\hline & $\mathrm{r}_{\mathrm{G}}$ & $-0.18^{\mathrm{ns}}$ & $-0.56^{\mathrm{ns}}$ & $-0.62^{+}$ & $-0.64^{\mathrm{ns}}$ & $-0.64^{\mathrm{ns}}$ \\
\hline \multirow{2}{*}{ NBT } & $\mathrm{r}_{\mathrm{F}}$ & & $-0.04^{\mathrm{ns}}$ & $0.24^{\mathrm{ns}}$ & $0.03^{\mathrm{ns}}$ & $0.47^{\mathrm{ns}}$ \\
\hline & $\mathrm{r}_{\mathrm{G}}$ & & $-0.05^{\mathrm{ns}}$ & $0.24^{\mathrm{ns}}$ & $0.03^{\mathrm{ns}}$ & $0.63^{\text {ns }}$ \\
\hline \multirow{2}{*}{ MBT } & $\mathrm{r}_{\mathrm{F}}$ & & & $0.91 * *$ & $0.89 * *$ & $0.65 *$ \\
\hline & $\mathrm{r}_{\mathrm{G}}$ & & & $0.99^{++}$ & $0.99^{+}$ & $0.85^{+}$ \\
\hline \multirow{2}{*}{ PT } & $\mathrm{r}_{\mathrm{F} \ldots}$ & & & & $0.95 * *$ & $0.88^{* *}$ \\
\hline & $\mathrm{r}_{\mathrm{G}}$ & & & & $0.98^{++}$ & $0.99^{++}$ \\
\hline \multirow{2}{*}{$\mathrm{PC}$} & $\mathrm{r}_{\mathrm{F}}$ & & & & & $0.81 * *$ \\
\hline & $\mathrm{r}_{\mathrm{G}}$ & & & & & $0.99^{++}$ \\
\hline
\end{tabular}

$\mathrm{AP}=$ average plant height $(\mathrm{cm}) ; \mathrm{NF}=$ number of leaves per plant; $\mathrm{NBT}=$ total bulb number; $\mathrm{MBT}=$ total bulb mass $(\mathrm{g}) ; \mathrm{PT}=$ total bulb yield $\left(\mathrm{t} \mathrm{ha}^{-1}\right) ; \mathrm{PC}=$ marketable bulb yield (diameter greater than $32 \mathrm{~mm})\left(\mathrm{t} \mathrm{ha}^{-1}\right) ; \mathrm{Nb}=$ number of cloves per bulb. $* * *$ and $\mathrm{ns}=$ significant at 1 and $5 \%$ probability and not significant, respectively by the t-test.,+++ and $n s=$ significant at 1 and $5 \%$ and not significant, respectively by the bootstrap method with 200 simulations. two characteristics $(\mathrm{Nb}: \mathrm{PT}-\mathrm{rG}=0.99$ and $\mathrm{rF}=0.88)$. It should be noted that the materials studied by these authors corresponded to varieties of garlic that already had desirable characteristics, whereas the one used in this study corresponded to most experimental genotypes.

For reliability of the results of the path analysis, the phenotypic correlation matrix between characters was tested for multicollinearity by the number of conditions proposed by Montgomery et al. (2012). Considering all variables, the correlation matrix presented severe multicollinearity $\mathrm{NC}=1459.23$. To circumvent multicollinearity, the methodology proposed by Carvalho \& Cruz (1996) was applied, which consists of applying a constant $\mathrm{k}$ in the diagonal of the matrix $X^{\prime} X$ of the estimator of least squares. The $\mathrm{k}$ value applied was 0.30 , making the presented results reliable. In this way, all variables were used in path analysis.

The adopted path analysis model explained $91 \%$ of the relationship of marketable yield of bulbs (PC), indicating that there is a direct effect of the explanatory variables (Table 2).

The characteristic that resulted in a greater direct effect on marketable yield of bulbs was the number of cloves per bulb (0.56), being higher than the value of the residual effect (0.32), and that possibly the cloves presented greater thickness and mass of the bulb. Singh et al. (2011), researching garlic culture in Karnal-India, found similar results, but using the characteristic weight of 50 garlic cloves, which could be related to the greater mass of these cloves and thickness, resulting in a direct effect with marketable yield of bulbs.

The high correlation between total and commercial bulb yield (0.96) is basically due to the indirect effect of the number of cloves per bulb (0.58) on total yield, that is, total yield correlated with commercial yield by the number of cloves per bulb. In the same way that the total correlations between total bulb mass and commercial bulb yield (0.96) and plant height and commercial bulb yield (0.56) are due to the indirect effect of number of cloves per bulb, 0.48 and 0.21 respectively. 
Table 2. Depletion of genotype correlations in components of direct and indirect effect involving the main dependent variable marketable yield (PC) of bulbs and the independent explanatory variables analyzed in ten garlic genotypes. Diamantina and Lavras, UFVJM and UFLA, 2017.

\begin{tabular}{|c|c|c|c|c|c|}
\hline \multicolumn{6}{|c|}{ Main: marketable bulbs yield } \\
\hline \multicolumn{2}{|l|}{$\mathbf{A P}$} & \multicolumn{2}{|c|}{ NF } & \multicolumn{2}{|l|}{ NBT } \\
\hline Direct effect on PC & 0.08 & Direct effect on PC & -0.07 & Direct effect on PC & -0.25 \\
\hline Indirect effect via NF & 0.05 & Indirect effect via NF & -0.06 & Indirect effect via NF & 0.01 \\
\hline Indirect effect via NBT & -0.03 & Indirect effect via NBT & 0.06 & Indirect effect via NBT & 0.02 \\
\hline Indirect effect via MBT & 0.13 & Indirect effect via MBT & -0.10 & Indirect effect via MBT & -0.01 \\
\hline Indirect effect via PT & 0.10 & Indirect effect via PT & -0.08 & Indirect effect via PT & 0.03 \\
\hline Indirect effect via $\mathrm{Nb}$ & 0.21 & Indirect effect via $\mathrm{Nb}$ & -0.25 & Indirect effect via $\mathrm{Nb}$ & 0.30 \\
\hline Total & 0.56 & Total & -0.53 & Total & 0.02 \\
\hline \multicolumn{2}{|l|}{ MBT } & \multicolumn{2}{|l|}{ PT } & \multicolumn{2}{|l|}{$\mathbf{N b}$} \\
\hline Direct effect on PC & 0.17 & Direct effect on PC & 0.14 & Direct effect on PC & 0.56 \\
\hline Indirect effect via NF & 0.06 & Indirect effect via NF & 0.05 & Indirect effect via NF & 0.03 \\
\hline Indirect effect via NBT & 0.05 & Indirect effect via NBT & 0.04 & Indirect effect via NBT & 0.03 \\
\hline Indirect effect via MBT & 0.01 & Indirect effect via MBT & -0.06 & Indirect effect via MBT & -0.14 \\
\hline Indirect effect via PT & 0.13 & Indirect effect via PT & 0.16 & Indirect effect via PT & 0.15 \\
\hline Indirect effect via $\mathrm{Nb}$ & 0.48 & Indirect effect via $\mathrm{Nb}$ & 0.58 & Indirect effect via $\mathrm{Nb}$ & 0.14 \\
\hline Total & 0.96 & Total & 0.96 & Total & 0.94 \\
\hline
\end{tabular}

Determination coefficient $=0.91$; Residual effect $=0.32$

$\mathrm{AP}=$ average plant height $(\mathrm{cm}) ; \mathrm{NF}=$ number of leaves per plant; $\mathrm{NBT}=$ total bulb number; $\mathrm{MBT}=$ total bulb mass $(\mathrm{g}) ; \mathrm{PT}=$ total bulb yield $\left(\mathrm{t} \mathrm{ha}{ }^{-1}\right) ; \mathrm{PC}=$ marketable bulb yield (diameter greater than $\left.32 \mathrm{~mm}\right)\left(\mathrm{t} \mathrm{ha}^{-1}\right) ; \mathrm{Nb}=$ number of cloves per bulb.

Therefore, the bulb with the highest number of cloves should be considered in the selection criteria to increase commercial bulb yield and choice of genotypes with the highest cloves number should be emphasized. This characteristic, number of cloves per bulb, may provide higher yields when used in planting (asexual propagation). This statement is confirmed by Castellanos et al. (2004) and Mahadeen (2011), who associated increased yield with the use of large cloves by the largest amount of nutritional reserve, thus providing the fastest establishment of the plant.

Although the number of total bulbs (NBT) was used to quantify bulb production, it had the lowest direct effect on commercial bulb yield $(-0.25)$ and low indirect effect on the other characteristics. This suggests that the NBT feature should be left out of path analysis when the most important selection feature is marketable bulb yield.

Based on the presented results, it is important to identify if there is an association of attributes with marketable bulb yield, that is, to direct high correlation variables with the basic variable, those that have a greater direct effect in favor of selection, so that the response correlated through indirect selection is efficient. Thus, it can be inferred that the genotypic correlations were superior in relation to the phenotypic correlations, thus evidencing greater contributions of the genetic factors between the characteristics in the two cultivation environments. The total bulb mass, total yield and number of cloves per bulb were strongly $(r>0.8)$ correlated with marketable yield of garlic. The number of cloves per bulb presented a relevant direct effect and indirect effect for the other characteristics on marketable bulb yield. Thus, to aid in breeding programs of these genotypes in both studied environments, the genotype selection criterion will be based on the highest number of cloves per bulb to increase commercial bulb yield.

\section{ACKNOWLEDGMENTS}

This work was carried out with the support of the Coordination of Improvement of Higher Education Personnel, Brazil (CAPES), Financing
Code 001, CNPq and FAPEMIG.

\section{REFERENCES}

BRAZIL. 1992. MAPA(Ministério da Agricultura, pecuária e abastecimento) - Portaria $\mathrm{N}^{\circ} 242$ de 17/09/1992.

CARVALHO, SP; CRUZ, CD. 1996. Diagnosis of multicollinearity: assessment of the condition of correlation matrices used in genetic studies. Brazilian Journal of Genetics 19: 479-484.

CASTELLANOS, JZ; VARGAS-TAPIA, P; OJODEAGUA, JL; HOYOS, G; ALCANTARGONZALEZ, G; MÉNDEZ, FS; ALVAREZSANCHEZ, E; GARDEA, AA. 2004. Garlic productivity and profitability as affected by seed clove size, planting density and planting method. HortScience 39: 1272-1277.

CHOTALIYA, P; KULKARNI, GU. 2017. Character association and path analysis for quantitative traits in garlic (Allium sativum). International Journal of Current Microbiology and Applied Sciences 6: 175-184.

CRUZ, CD. 2013. Genes: a software package for analysis in experimental statistics and quantitative genetics. Acta Scientiarum Agronomy 35: 271-276.

CRUZ, CD; REGAZZI, AJ; CARNEIRO, PCS. 2012. Modelos biométricos aplicados ao melhoramento genético. Viçosa: UFV. 514p.

CRUZ, CD; CASTOLDI, FL. 1991. Decomposição da interação genótipo $\mathrm{x}$ ambiente em partes simples e complexas. Revista Ceres 38 : 422-430.

DUBEY, BK; SINGH, RK; BHONDE, SR. 2010. 
Variability and selection parameters for yield and yield contributing traits in garlic (Allium sativum L.). Indian Journal of Agricultural Sciences 80: 737-41.

ETOH, T. 1980. An attempt to obtain binucleat pollen of garlic (Allium sativum L.) Memoirs of the Faculty of Agriculture 16: p. 65-73.

GOMES, FP; GARCIA, CA. 2002. Estatística aplicada a experimentos agronômicos $e$ florestais. Piracicaba: Fundação de Estudos Agrários Luiz de Queiroz. 21p.

MAHADEEN, AY. 2011. Influence of clove weight on vegetative growth and yield of garlic (Allium sativum L.) grown under drip irrigation. Jordan Journal of Agricultural Sciences 173: 1-14.

MONTGOMERY, DC; PECK, EA; VINING, GG. 2012. Introduction to linear regression analysis. New York: John Wiley. 672p.

MORAVČEVIĆ, D; BJELIĆ, V; SAVIĆ, D; VARGA, JG; BEATOVIĆ, D; JELAČIĆ, S; ZARIĆ, V. 2011. Effect of plant density on the characteristics of photosynthetic apparatus of garlic (Allium sativum var. vulgare L.). African Journal of Biotechnology 10: 15861-15868.

PANTHEE, DR; KC, RB; REGMI, HN; SUBEDI, PP; BHATTARAI, S; DHAKAL, J. 2006. Diversity analysis of garlic (Allium sativum L.) germplasms available in Nepal based on morphological characters. Genetic Resources and Crop Evolution 53: 205-206.

PEREIRA, AR; MACHADO, EC. 1987. Análise quantitativa do crescimento de comunidade vegetal. Campinas: Instituto Agronômico. 33p (Boletim técnico, 114).

PEREIRA, MG; AMARAL JÚNIOR, AT. 2001. Estimation of genetic components in popcorn based on the nested design Crop Breeding and Applied Biotechnology, 1: 3-10.

POOLER, MR; SIMON, PW. 1993. Garlic flowering in response to clone, photoperiod, growth temperature, and cold storage. Hort Science 28: 1085-1086.

REZENDE, BR; SILVA, AR. 2015. Análise de trilha da produtividade de alho com inclusão de variável multicategórica. Multi-Science Journal 1: 13-16.

SHIMONO, H. 2011. Rice genotypes that respond strongly to elevated $\mathrm{CO}_{2}$ also respond strongly to low planting density. Agriculture, Ecosystems and Environment, 141: 240-243.

SILVA, FJ; HISATUGO, EY; SOUZA, JP. 2016. Efeito da luz na germinação e desenvolvimento de plântulas de pinhão-manso (Jatropha curcas L.) de distintas procedências. Hoehnea 43: 195-202.

SINGH, RK; DUBEY, BK; BHONDE, SR; GUPTA, RP. 2011. Correlation and path coefficient studies in garlic (Allium sativum L.). Journal of Spices and Aromatic Crops 20: 83-85.

SINGH, SR; AHMED, NA; LAL, S; AMIN, A; AMIN, M; GANIE, SA; JAN, N. 2013. Character association and path analysis in garlic (Allium sativum L) for yield and its attributes. SAARC Journal of Agriculture 11: 45-52.

SOUZA, RJ; PAULA, MB; CECÍLIO FILHO, AB. 1999. Alho. In: RIBEIRO, AC; GUIMARÃES, PTG; ALVAREZ VHV (eds). Recomendação para o uso de corretivos e fertilizantes em Minas Gerais. v.5. Aproximação. Viçosa: Comissão de Fertilidade do Solo do Estado de Minas Gerais. p.178.

SOUZA, RJ; MACÊDO, FS. 2009. Cultura do alho: tecnologias modernas de produção. Lavras: UFLA. p.181.

TSEGA, K; TIWARI, A; WOLDETSADIK, K, 2010. Genetic variability, correlation and path coefficient among bulb yield and yield traits in Ethiopian garlic germplasm. Indian Journal of Horticulture 67: 1489-99.

YAO, H; ZHANG, Y; YI, X; HU, Y; LUO, H; GOU, L; ZHANG, W. 2015. Plant density alters nitrogen partitioning among photosynthetic components, leaf photosynthetic nitrogen use efficiency in field-grown cotton. Field Crops Research 184: 39-49. 